Review

\title{
Functional Role of Probiotics and Prebiotics on Skin Health and Disease
}

\author{
Vasiliki Lolou and Mihalis I. Panayiotidis * \\ Department of Applied Sciences, Northumbria University, Newcastle Upon Tyne NE1 8ST, UK; \\ vasiliki.lolou@northumbria.ac.uk \\ * Correspondence: m.panagiotidis@northumbria.ac.uk; Tel.: +44-(0)191-227-4503
}

Received: 6 March 2019; Accepted: 10 May 2019; Published: 17 May 2019

\begin{abstract}
Scientific and commercial interest of probiotics, prebiotics and their effect on human health and disease has increased in the last decade. The aim of this review article is to evaluate the role of pro- and prebiotics on the normal function of healthy skin as well as their role in the prevention and therapy of skin disease. Lactobacilli and Bifidobacterium are the most commonly used probiotics and thought to mediate skin inflammation, treat atopic dermatitis (AD) and prevent allergic contact dermatitis (ACD). Probiotics are shown to decolonise skin pathogens (e.g., P. aeruginosa, S. aureus, A. Vulgaris, etc.) while kefir is also shown to support the immunity of the skin and treat skin pathogens through the production of antimicrobial substances and prebiotics. Finally, prebiotics (e.g., Fructo-oligosaccharides, galacto-oligosaccharides and konjac glucomannan hydrolysates) can contribute to the treatment of diseases including $\mathrm{ACD}$, acne and photo aging primarily by enhancing the growth of probiotics.
\end{abstract}

Keywords: probiotics; prebiotics; skin health; skin disease; dermatitis; skin infections

\section{Introduction}

Fermented food has been part of our diet, in addition to being used for therapeutic purposes, as early as 7000 BC from Egyptians, Greeks and Italians [1-3]. Some of the most ancient fermented foods used in history is wine, bread and milk products such as yoghurt. In fact, it is documented that Georgians were using wine in their diet as early as $6000 \mathrm{BC}$, whilst fermented dairy products were used for the treatment of diarrhea and other gastroenteric infections [4,5]. The relationship between human health and microbiota was first mentioned in 1907, by Elie Metchnikoff, when the enhanced longevity due to the intentionally present bacteria in yogurt was described [6]. In addition, fermented food became famous after Werner Kollath first introduced the term "Probiotic". The food industry has used probiotics in their products as an aiding ingredient and/or as a preservative means since 1989 [7]. With the evolution of food processing and preservation and the consumer's interest for a healthier and more balanced diet, probiotics became one of the most marketable ingredients. According to the World Health Organization (WHO), probiotics are live microorganisms that "when administered in adequate amounts, confer a health benefit on the host" [8]. Most common species of probiotics belong in the families of Lactobacillus, Bifidobacterium and Streptococcus [9] with the first two families being mostly used in studies related to human health [10]. As these microorganisms are naturally found in the gut microbiota, most studies are focused on their effects in the context of the natural function in the gut and as preventive or therapeutic agents against disease development [11-18]. To this end, probiotics have been used for the study and treatment of intestinal diseases such as gastroenteritis [19], intestinal hyperpermeability [20], urinary tract infection [21], intestinal dysbiosis [22], irritable bowel syndrome [23], Crohn's disease [24], colon cancer [25,26], ulcerative colitis [27,28] and peptic ulcer [23]. In particular, many studies have shown their involvement in regulating signaling molecules like 
NFкB, MAPK, PPAR $\gamma$, HSP, etc. by either activating or inhibiting their expression profile depending on the microorganism studied. Such effect(s), in turn, can trigger other signaling events including perturbations in the (i) phosphorylation content of IKB $\alpha$, (ii) activation status of $\mathrm{p} 38$, (iii) inhibition of nuclear binding by p65 as well as (iv) induction of PPAR $\gamma$ mRNA levels [29-61]. In addition, probiotics have been extensively utilized in the context of intervention studies towards prevention and/or treatment of a number of human diseases including those of the skin like atopic dermatitis [AD] [62-69], allergic rhinitis [66,70,71] and wound healing [72-79] being some of the major ones (Figure 1).

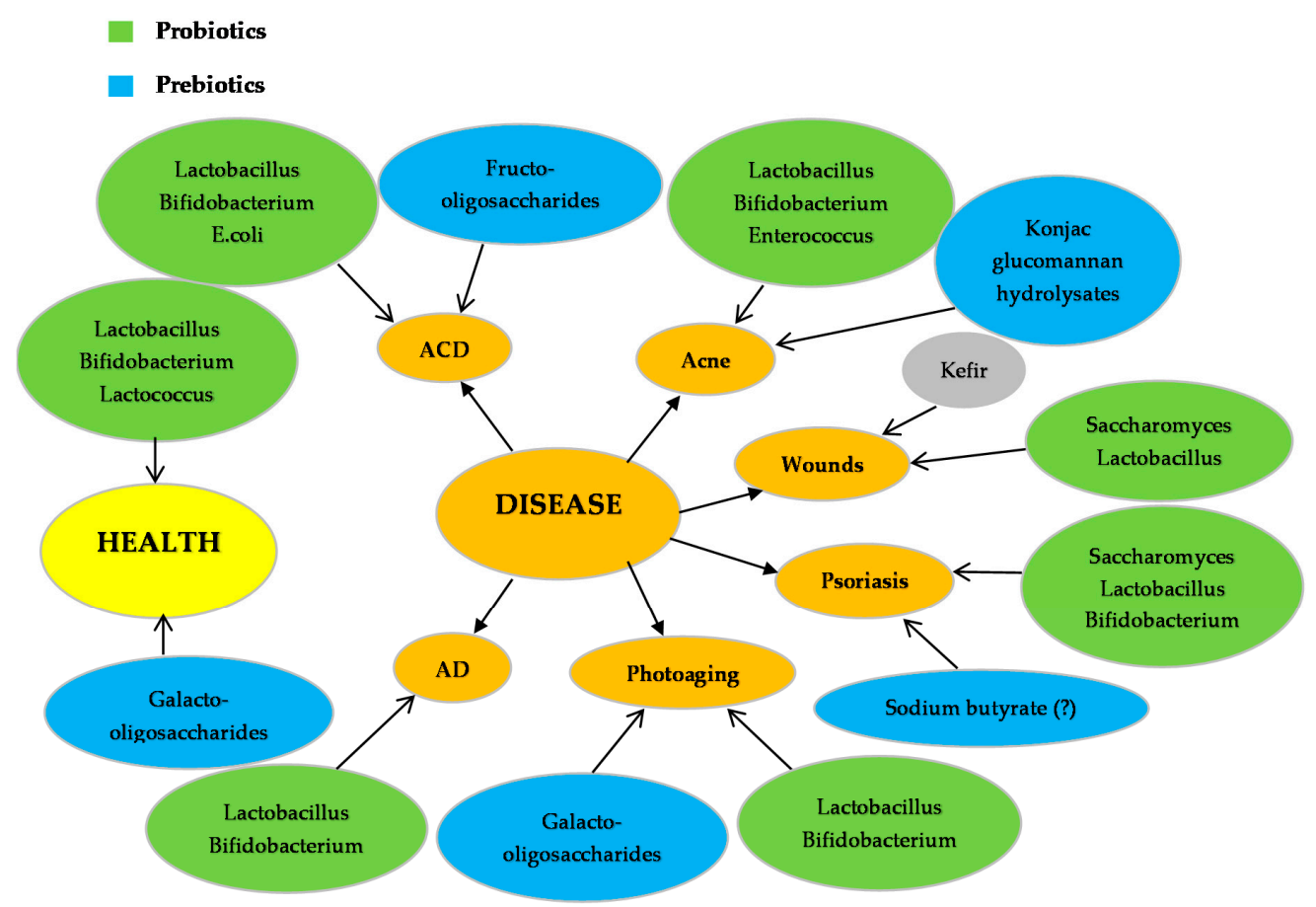

Figure 1. The role of probiotics and prebiotics on skin health and disease including Allergic Contact Dermatitis (ACD), Acne, Wounds, Psoriasis, Photoaging and Atopic Dermatitis (AD).

On the other hand, with the term "prebiotics" we refer to specific fermented components that enhance changes in the composition and the activity of the gut microflora in favor to the host [80]. Prebiotics are characterized by low dosage activity, absence of side effects and persistence through the gut [81]. The most commonly known prebiotics are oligosaccharides (OS; e.g., glycans), fructans (inulin-type), sugar alcohols and complex polysaccharides (e.g., $\beta$-glucans, cellulose) [82,83]. The available literature on prebiotics and their effect on human health is limited, compared to the probiotics, and it is often included in several probiotic studies. These non-digestible compounds are known for their bifidogenic effect, which varies depending on the type of prebiotic. This is based on the fact that long-chain OS are fermented in the entire gut whereas the short-chain ones are only processed in the ascending colon and the caecum. Breast milk mostly consists of prebiotic OS and as being the first food for infants; it provides the initial intestinal microbiota whose growth is supported by these OS. Furthermore, recent studies have shown the ability of prebiotics to enhance calcium absorption and have an effect on bone structure as well [82]. Moreover, these compounds are shown to affect the immune system by increasing IgA, CD4+ cells, INF- $\gamma$ and IL-4 in spleen and mesenteric lymph nodes [84-86]. Additionally, other studies on healthy participants have shown a decrease of toxic fermentation metabolites in the colon (e.g., $\left[\mathrm{H}_{4}\right]$ tyrosine and lactose-[N]ureide) after consumption of pro- (e.g., L. casei) and prebiotics (e.g., n9; lactulose) [87].

Finally, the skin represents the largest organ in the human body and as such, its main function is to act as a barrier to extrinsic factors including physical, chemical and microbial threats. In this 
context, a strong symbiotic relationship between microorganisms exists that constitutes its microbiota. This natural microflora supports the immune system in various ways including the production of natural antimicrobial compounds (e.g., lactic acid) as well as activation of various signaling pathways and modulation of the inflammatory response [88,89]. In this review article, we aim to focus on the beneficial role of pro- and prebiotics on skin health as well as their therapeutic and/or preventive role on specific skin diseases.

\section{Probiotics and Prebiotics on Skin Health}

There is a rather small number of studies on healthy subjects to show a beneficial effect of probiotics on skin health (Figure 1) [18,61,90-92]. In one such study, when the L. lactis strain; H61 was supplemented on middle-aged women, daily for eight weeks, an improvement on skin elasticity and body characteristics were observed (e.g., skin appeared more hydrated and the hair follicles had improved) [92]. Similarly, in another such study, oral intakes of L. plantarum; HY7714 from a group of subjects aged 41-59 years old also confirmed the effect of probiotics on increasing skin moisture, decreasing the depth of existing wrinkles and improving the overall skin gloss and elasticity [61]. Moreover, other studies have shown that when probiotic and para-probiotic L. reuteri were administrated orally, for 12 weeks, an increase in melanin and a decrease in Trans-Epidermal Water Loss (TEWL) were observed [91]. Such effects are in agreement with studies utilizing other probiotics (e.g., L. rhamnosus, B. breve Strain Yakult, L. lactis, S. thermophilus) and prebiotics (e.g., galacto-oligosaccharides; GOS) (Figure 1) all of which have indicated (i) improved levels of skin hydration and cathepsin-L-like activity levels (an indicator of keratinocyte differentiation and a marker of skin barrier function) as well as (ii) reduced urine and serum phenol levels (e.g., toxic by-products formed by gut bacteria) [90,93].

\section{Probiotics and Prebiotics on Skin Disease}

\subsection{Dermatities}

\subsubsection{Atopic Dermatitis}

Atopic Dermatitis (AD), also known as atopic eczema, is a skin inflammatory disease that is observed in early stages of life and is linked with allergic rhinitis, food allergies and asthma, all of which are more prevalent in children suffering from this disease. One of the most common symptoms of eczema, apart from itchiness, is the reduction of barrier function that leads to allergen exposure and overall reduction of the TEWL, leading to dry skin [94]. In an AD model, allergens can penetrate the stratum corneum, which is altered by the epidermal epithelium deformities. Moreover, symptoms include the presence of pathogenic microorganisms, such as $S$. aureus, that colonize and infect the subjects. Another significant aspect of AD is its relationship with the gut microbiota. More specifically, the balanced microbial profile of the mucosa can promote the production of immunoglobulin A (IgA) which supports the defensive mechanisms of the gut membrane, whilst enhancing the expression of the Transforming Growth Factor (TGF) [95]. A relationship between the gut microflora and the development of AD was also observed in infants at high risk for developing AD showing an increased number of clostridia compared to control, disease free infants [96].

Specific probiotic microorganisms are shown to have a preventing role on AD and mediate the symptoms of the disease (Figure 1). They appear to do so by influencing a number of biological processes not only in $\mathrm{AD}$ but rather in a wide range of skin diseases (e.g., acne, psoriasis, photo aging, wounds, etc.) (Table 1 and Figure 2). More specifically, in a recent study, supplementation with L. rhamnosus in combination with $L$. reuteri improved the severity of eczema by $56 \%$ in children suffering from AD [65]. Moreover, in another study, L. rhamnosus was utilized as a supplemented probiotic, to women four weeks before delivery and six months postnatal, demonstrating to significantly reduce the risk of children developing AD during their first seven years of age [66]. Finally, when infants at high risk of developing AD were supplemented with a mix of probiotic microorganisms (e.g., 
L. acidophilus, B. bifidum and B. lactis), during pregnancy and after birth, they showed a reduction of immunoglobulin E (Ig-E) associated eczema by $40 \%$ [62].

Table 1. Probiotics and their effect on skin diseases.

\begin{tabular}{|c|c|c|c|}
\hline Probiotics & Disease & Function & Reference \\
\hline L. rhamnosus & $\mathrm{AD}^{1}$ & $\begin{array}{l}\text { Improvement of severity of eczema, reduction of } \\
\text { risk of } A D \text { development in infants }\end{array}$ & {$[65,66]$} \\
\hline L. reuteri & $\begin{array}{c}\mathrm{AD} \\
\text { Infections (S. aureus) }\end{array}$ & $\begin{array}{l}\text { Improvement of eczema. Blocks integrin, } \\
\text { Reduces cell death due to S. aureus infection }\end{array}$ & {$[65,97]$} \\
\hline $\begin{array}{c}\text { L. delbrueckii } \\
\text { subspecies bulgaricus }\end{array}$ & Acne & Improvement of Acne symptoms (Acne Vulgaris) & [98] \\
\hline L. sporogenes & Psoriasis & $\begin{array}{l}\text { Improvement of symptoms, reduction of blood } \\
\text { sugar levels and fever }\end{array}$ & [99] \\
\hline L. plantarum & Photoaging & $\begin{array}{c}\text { Inhibition of MMP-1, MMP-2, MMP-9 and } \\
\text { MMP-13 }{ }^{2} \text {, enhancement of procollagen } \\
\text { expression, inhibition of phosphorylation of Jun } \\
\text { N-terminal kinase, increase of } \\
\text { palmitoytransferase mRNA levels, decrease of } \\
\text { ceramide mRNA levels, reduction of wrinkles } \\
\text { and epidermal thickness }\end{array}$ & {$[100,101]$} \\
\hline L. fermentum & Infections (wounds) & $\begin{array}{l}\text { Production of gNO }{ }^{3} \text {, increases productions of } \\
\text { IL- } 1^{4} \text { and TGF- } \beta^{5} \text { cytokines }\end{array}$ & {$[102,103]$} \\
\hline L. acidophilus & $\begin{array}{c}\mathrm{AD} \\
\mathrm{ACD}^{6} \\
\text { Infections (S. aureus) } \\
\text { Acne }\end{array}$ & $\begin{array}{l}\text { Reduction of Ig-E }{ }^{7}, \text { reduction of eczema, } \\
\text { Increase of TGF- } \beta \text {, Foxp3 }{ }^{8}, \text { IFN- } \gamma^{9} \text { and IL-10 } 10 \\
\text { expression, Inhibition of S. aureus infection, } \\
\text { reduction of acne symptoms }\end{array}$ & $\begin{array}{c}{[62,98,104,} \\
105]\end{array}$ \\
\hline $\begin{array}{l}\text { L. casei } \\
\text { L. salivarius }\end{array}$ & $\begin{array}{c}\text { ACD } \\
\text { Infections (MRSA) }{ }^{11}\end{array}$ & $\begin{array}{l}\text { Reduction of skin inflammation, inhibition of } \\
\text { IFN- } \gamma, \text { CD } 8^{+} \mathrm{T} \text { cells, increase in IL-10 production, } \\
\text { activation of CD } 4^{+} \mathrm{CD} 25^{+} \mathrm{T} \text { cells, } \\
\text { inhibition of MRSA }\end{array}$ & [105-107] \\
\hline B. bifidum & $\begin{array}{l}\text { AD } \\
\text { Acne }\end{array}$ & $\begin{array}{c}\text { Reduction of Ig-E, reduction of development of } \\
\text { AD in infants, reduction of Acne } \\
\text { Vulgaris symptoms }\end{array}$ & {$[62,98]$} \\
\hline B. lactis & $\mathrm{AD}$ & $\begin{array}{l}\text { Reduction of Ig-E, reduction of development of } \\
\text { AD in infants. }\end{array}$ & [62] \\
\hline B. pseudolongum & $\mathrm{ACD}$ & Reduction of allergic reaction on mice & [108] \\
\hline B. longum & Photoaging & $\begin{array}{l}\text { Prevention of TEWL }{ }^{12} \text {, reduction of skin } \\
\text { erythema, increase of mRNA expression of CD44, } \\
\text { TIMP- } 1^{13} \text { and Col1 }{ }^{14} \text {. }\end{array}$ & [109] \\
\hline B. breve strain Yakult & Photoaging & $\begin{array}{l}\text { Prevention of loss of elasticity, suppression of } \\
\text { elastase, activation of IL-1 } \beta\end{array}$ & {$[38,110]$} \\
\hline B. infantis & Psoriasis & Reduction of plasma TNF- $\alpha^{15}$, increase of IL- 6 & [111] \\
\hline S. epidermidis & Acne & $\begin{array}{l}\text { Growth inhibition of Propionibacterium acnes } \\
\text { and Acne Vulgaris by competitive exclusion }\end{array}$ & [112] \\
\hline E. faecalis & Acne & $\begin{array}{l}\text { Reduction of inflammation areas, production } \\
\text { of bacteriocins }\end{array}$ & [113] \\
\hline E. coli Nissle 1917 & ACD & $\begin{array}{c}\text { Increase of TGF- } \beta \text {, Foxp3, IFN- } \gamma \text { and } \\
\text { IL-10 expression }\end{array}$ & [114] \\
\hline
\end{tabular}

Production of antimicrobial substances (lactic acid, acetic acid, hydrogen peroxide,

Kefir grains Infections bacteriocins), Healing of P. aeruginosa infected wounds, Inhibition of S. aureus, S. salivarius, $S$. pyogenes, P. aeruginosa, C. albicans, S. tympimurium,

L. monocytogenes and E. coli growth

\footnotetext{
${ }^{1}$ Atopic Dermatitis; ${ }^{2}$ Matrix Metalloproteinases (MMPs)-1,-2,-9,-13; ${ }^{3}$ Nitric Oxide; ${ }^{4}$ Interleukin $1 ;{ }^{5}$ Transforming Growth Factor $\beta ;{ }^{6}$ Allergic Contact Dermatitis; ${ }^{7}$ Immunoglobulin E; ${ }^{8}$ Forkhead box P3; ${ }^{9}$ Interferon gamma;

${ }^{10}$ Interleukin 10; ${ }^{11}$ Methicilin Resistant Staphylococcus aureus; ${ }^{12}$ Trans Epidermal Water Loss; ${ }^{13}$ Tissue inhibitor of metalloproteinases $1 ;{ }^{14}$ Collagen $1 ;{ }^{15}$ Tumor Necrosis Factor.
} 


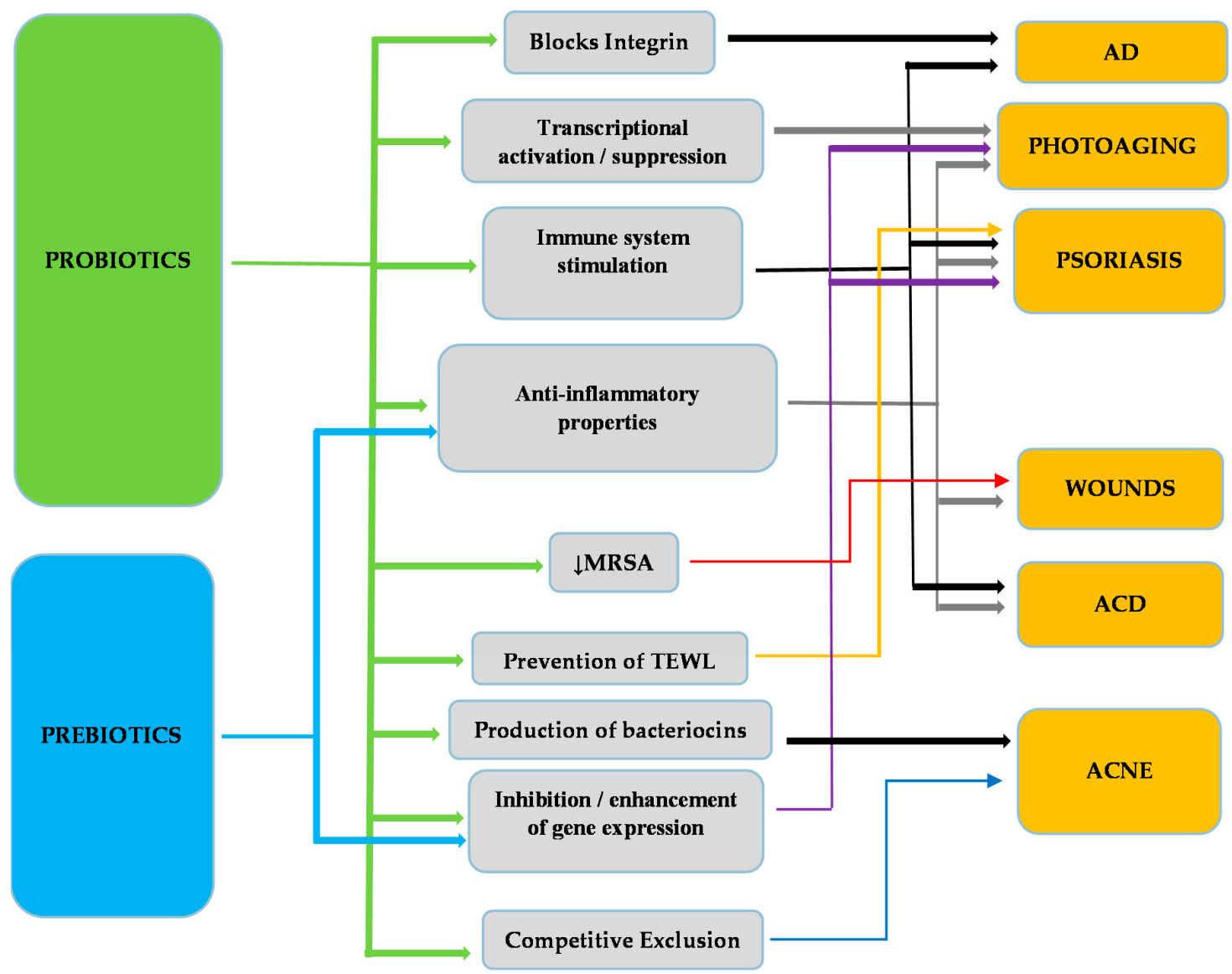

Figure 2. Linkage of various skin diseases with their respective mode of action through which proand prebiotics exert a beneficial effect. Methicilin Resistant Staphylococcus aureus (MRSA); Trans Epidermal Water Loss (TEWL).

\subsubsection{Allergic Contact Dermatitis}

Allergic contact dermatitis (ACD), also known as eczema, is caused after the skin comes in contact with an allergenic substance capable of causing an allergic reaction. Symptoms vary but include skin inflammation, itchiness, dry skin, blisters, etc. The allergic reaction is regulated by $\mathrm{CD} 4^{+} \mathrm{T}$ cells in a manner where peptides derived from allergens activate Th2-type cytokines (produced by these CD4 ${ }^{+}$ T lymphocytes) including interleukins 4, 5 and 13 [117]. Overall, pro- and prebiotics are shown to have a preventing role on ACD and consequently mediate its symptoms (Figure 1).

L. case $i$ is found to reduce skin inflammation either by targeting the inhibition of INF- $\gamma$ (responsible in producing $\mathrm{CD} 8^{+}$effector $\mathrm{T}$ cells) [106] or via mechanisms that include the involvement of regulatory $\mathrm{CD}^{+} \mathrm{T}$ cells [107]. In addition, the microorganism has also been shown to increase the production of IL-10 by promoting the activation of $\mathrm{CD}^{+} 4 \mathrm{CD} 25^{+}$Tregs thus further supporting its specific mode of action against skin inflammation [107] (Table 1 and Figure 2). On the other hand, E. coli Nissle $1917(\mathrm{EcN})$ is another probiotic microorganism shown to prevent ACD by means of increasing the number of Foxp $3^{+}$cells (suppress antigen priming of lymphocytes) as well as the expression of TGF- $\beta$, IFN- $\gamma$ and IL-10 (regulatory cytokine network) thus suggesting an immunomodulatory function against allergen-induced dermatitis [114] (Table 1 and Figure 2). Similar observations were made in the case of the para-probiotic L. acidophilus strain L-92 which was also shown to induce the activation of $\mathrm{CD}^{+} 4 \mathrm{CD} 25^{+} 3^{+}$Tregs and consequently suppress ACD [104] (Table 1 and Figure 2).

Finally, in another study, consumption of the prebiotic fructo-oligosaccharide resulted in suppressed skin inflammation due to a favorable change in the population of the intestinal microbiota by means of increasing the population of B. pseudolongum. This, in turn, has led to reduced contact 
hypersensitivity associated with proliferation of B. pseudolongum in the intestinal tract of the mice [108] (Table 2).

Table 2. Prebiotics and their effect on skin disease.

\begin{tabular}{cccc}
\hline Prebiotics & Disease & Function & Reference \\
\hline Fructo-oligosaccharides & ACD & Reduction of allergic reaction. & {$[108]$} \\
\hline $\begin{array}{c}\text { Konjac glucomannan } \\
\text { hydrolysates (GMH) }\end{array}$ & Acne & $\begin{array}{c}\text { Inhibition of Acne Vulgaris and P. acnes, growth } \\
\text { enhancement of lactic acid bacteria. }\end{array}$ & {$[118,119]$} \\
\hline Galacto-oligosaccharides & Photoaging & $\begin{array}{c}\text { Prevention of }{ }^{1} \text { TEWL, reduction of skin } \\
\text { erythema, increase of mRNA expression of CD44, } \\
\text { 2TIMP-1 and }{ }^{3} \text { Coll. }\end{array}$ & {$[109]$} \\
\hline Sodium Butyrate (?) & Psoriasis & Increases Fas, ${ }^{4}$ TGF- $\beta$ and p52 & {$[120-123]$} \\
\hline Oligo-saccharides & Photoaging & $\begin{array}{c}\text { Modulation of the expression of elastase-type } \\
\text { proteases through elastin receptors }\end{array}$ & {$[124,125]$} \\
\hline
\end{tabular}

${ }^{1}$ Trans Epidermal Water Loss; ${ }^{2}$ Tissue inhibitor of metalloproteinases $1 ;{ }^{3}$ Collagen $1 ;{ }^{4}$ Transforming Growth Factor $\beta$.

\subsection{Skin Infections}

\subsubsection{Wounds}

Most skin infections are initiated when an opening of the skin is infected with a pathogen. Briefly, when the cohesion of the skin is disrupted (either accidentally or as an effect of a disease) it forms a wound which is characterized by torn skin or by a hematoma of the tissue. In the case of a torn tissue, there are four stages descriptive of the healing process: (i) stopping the blood flow to the damaged blood vessels (hemostasis); (ii) initiating an inflammatory response which prevents potential pathogenic microorganisms to infect the wound and maintains the microbial balance of the skin; (iii) stimulating production of growth factors causing (iv) proliferation of fibroblasts and production of extracellular matrix proteins (e.g., hyaluronan and collagen) [126]. Furthermore, these stages are characterized by the involvement of other events including generation of oxidative stress [127].

There is a great scientific interest regarding the role of skin microflora in the process of wound healing as it has been shown that the absence of microbiota can decrease the healing time [128]. On another note, wound infections occur when exogenous bacteria become dominant over the systemic and local factors of host resistance. Therefore, it is only when a balance is achieved between bacteria and host that allows for the normal processes of wound healing to proceed [129]. Over the years, scientists have turned their interest to topical application of specific probiotic microorganisms in order to evaluate their effectiveness in preventing wound inflammation as well as improving on the speed of the healing process itself. In one such study, when burn wounds were treated with Saccharomyces cerevisiae an overall improvement on the healing process was observed [130]. More specifically, an increase in the expression levels of collagen type 1 and transcription growth factor beta 1 (TGF- $\beta 1$ ) were observed accompanied by improved morphological and biomechanical characteristics of the healing wounds [130].

Meticillin-resistant Staphylococcus aureus (MRSA) is one of the most widely known pathogens with the ability to infect wounds [131]. A number of studies have shown the capacity of specific probiotics (e.g., L. acidophilus and L. casei) to act as antibacterial agents against MRSA [105] (Table 1 and Figure 2). More specifically, the growth of the pathogen was found to be inhibited and eliminated by $99 \%$ after $24 \mathrm{~h}$ at $37^{\circ} \mathrm{C}$ incubation [105]. Moreover, in another study, three different probiotics (e.g., L. reuteri, L. rhamnosus and L. salivarius) were tested against S. aureus infection on epidermal keratinocytes [97]. Overall, it was found that L. reuteri and L. rhamnosus (but not L. salivarius) reduced the ability of the pathogen to induce keratinocyte cell death. This observation was directly associated with the ability of $L$. reuteri to inhibit the adherence and invasion of the pathogen to keratinocytes while $L$. 
salivarius did not. Furthermore, the degree of protection was greater in L. reuteri than L. rhamnosus [97] (Table 1). To conclude, given that $S$. aureus adheres with the epidermal keratinocyte cells via the $\alpha 5 \beta 1$ integrin, it was suggested that both of the protective probiotics reduce keratinocyte cell death by competitively excluding the pathogen from the integrin's binding sites on these skin cells [97]. Finally, antibiotic properties of probiotics have been also documented in experimental settings where wounds, infected with S. aureus, were treated with patches of L. fermentum. In these experiments, it was shown an increased wound closure concomitant with production of nitric oxide (gNO) induced by the probiotic [102] (Table 1 and Figure 2). In general, gNO is known to mediate the process of wound healing through promoting the production of IL-1, TGF- $\beta$ and cytokines all of which play a major role in immune response and inflammation [103].

In addition, a number of other studies have focused on topical applications of kefir and other fermented products because of their well-known anti-microbial and healing properties. Kefir is the product of milk fermentation that contains grains characterized by specific starter cultures used in the fermentation process [132]. These grains include (i) L. kefiri, (ii) species of the genera Leuconostoc, Lactococcus and Acetobacter, (iii) lactose fermenting (e.g., K. marxianus) as well as (iv) non-lactose fermenting (e.g., S. unisporus, S. cerevisiae and S. exiguous) yeasts [132]. However, there are many more microorganisms found in Kefir grains including the species Lactobacilli, Streptococci, Lactococci, Enterococci, Bacillus, etc. The composition of kefir grains varies depending on their origin and the microorganisms they contain [133]. Another aspect that can change the effect and the composition of kefir is the fermentation time and conditions [134-136]. Collectively, the antimicrobial activity of kefir is the result of the composition of the product that is high in lactic acid, acetic acid, hydrogen peroxide and bacteriocins all of which can have an effect on the growth of pathogens [137] (Table 1 and Figure 1). Consequently, the complexity of the kefir grains (and kefir itself) has raised the scientific interest in the context of exploring any potential effect on the growth of existing microorganisms in the human body. To this end, when B. bifidum PRL2010 (a dominant microorganism in the human gut) was cultured in the presence of kefir and/or kefiran (the polysaccharide produced by kefir), it was shown that the glycans present in kefir had a beneficial role on the growth of the bacteria (perhaps due to the increased transcriptional activation of genes related to the metabolisms of glycans) [138]. Furthermore, a few studies have documented a protective effect of kefir on the wound healing process $[79,115,137,139]$. To this end, one of the biggest challenges in wound healing is the infection of burn wounds from the antibiotic resistant pathogen P. aeruginosa. As a result, this pathogen is responsible for complications on serious illnesses such as hospital acquired infections and sepsis syndromes [73-75]. Experiments on burn wounds (after contamination with P. aeruginosa and then treatment with kefir) showed a reduction of their size accompanied by reduced healing time when kefir was administered alone than in the co-presence of silver sulfadiazine (a common topical antibiotic used for the treatment of P. aeruginosa on burn wounds). Such findings highlight the potential pharmaceutical use of kefir on the treatment of burn wounds [115]. Finally, in another study, burn wounds were contaminated with 8 different pathogens (e.g., S. aureus, S. salivarius, S. pyogenes, P. aeruginosa, C. albicans, S. tympimurium, Listeria monocytogenes and E. coli) and when kefir and/or kefiran were applied to the subject's infected areas the growth of these pathogens was considerably reduced [116].

\subsubsection{Acne}

Although not many studies have been conducted on the effect of pro- and prebiotics in acne, a number of them suggest a potential preventive role of pro- and prebiotics on acne thereby mediating its symptoms (Figure 1). More specifically, in a study utilizing a mixture of probiotics (L.acidophilus, B. bifidum and L. delbrueckii), the side effects of minocycline administration (an antibiotic used for the treatment of $A$. Vulgaris) were reduced while still being effective in exerting a synergistic anti-inflammatory effect. These results suggest a potential use of the probiotic mixture as an alternative treatment option against $A$. Vulgaris in addition to being capable of reducing adverse side effects after chronic systemic antibiotic use [98]. Acne is enhanced in the presence of the bacterium P. acnes. 
On the other hand, S. epidermidis is naturally found on skin and has been shown to antagonize P. acnes thus highlighting its therapeutic potential against acne [112] (Table 1 and Figure 2). In another study, the therapeutic role of E. faecalis SL-5 on acne was also evaluated with results demonstrating that bacteriocin (CBT SL-5; an antimicrobial compound produced by E. faecalis) was capable of reducing inflammation suggesting the use of E. faecalis as an alternative approach to acne therapy thereby avoiding the extensive use of antibiotics [113] (Table 1 and Figure 2).

Finally, despite the lack of literature on the effect of prebiotics to skin disease, konjac glucomannan hydrolysates (GMH) have also been shown to inhibit A. Vulgaris and P. acnes by stimulating the growth of probiotic microorganisms including lactobacilli. To this end, it is noteworthy that lactic acid bacteria show selectivity towards a mannose, a glucose substrate (found in GMH), because of the nature and accessibility of these sugars as carbon sources [118,119] (Table 2 and Figure 2).

\subsection{Psoriasis}

Psoriasis is a skin condition that causes a variety of symptoms including flaky skin (patches), itchiness and redness of the area. It is a non-contagious disease and it can affect individuals of any age [140]. There are different types of the disease including pustular psoriasis, psoriatic arthritis and plaque. Even though the literature on the effects of probiotics to skin inflammation and dermatitis is extensive, little is known on their effects on psoriasis. Nevertheless, a number of studies have been conducted on the effect of pro- and prebiotics in psoriasis suggesting a potential preventive role of their action by means of mediating the symptoms of the disease (Figure 1).

In general, studies on the role of the human epidermal microbiome in psoriasis and other skin diseases revealed that $S$. epidermidis (although a permanent member of the normal human microbiota) is second most prevalent staphylococcal species only to S. aureus [141]. To this end, a recent study was shown that $S$. aureus was at significantly higher levels on diseased skin as opposed to $S$. epidermidis and $P$. acnes both of which were shown to be in abundance on healthy skin thereby suggesting that psoriasis is highly associated with the microbial load of the skin [142]. To this end, another study has shown that the abundance of $S$. cerevisiae is decreased in psoriasis patients and that treatment with dimethylfumarate (DMF) successfully restored its levels, a finding of utmost importance given the well-known and beneficial immunomodulatory properties of this yeast species [143]. Moreover, extensive research indicates a strong link between potential mediators of $\mathrm{T}$ cell activation and the development of the disease. In particular, $\mathrm{CD}^{+} \mathrm{T}$ cells are linked with the development of psoriatic arthritis whilst probiotics regulate $\mathrm{T}$ cells and reduce skin inflammation and dryness of the skin [144] (Table 1 and Figure 2). In a recent case report, the probiotic microorganism L. sporogenes was successfully used for the treatment of pustular psoriasis as evident by an overall improvement of the appearance of lesions and patient's general condition [99] (Table 1). A year later, Groeger et al., 2013 studied the immuno-regulatory effects of $B$. infantis in patients with ulcerative colitis, chronic fatigue syndrome and psoriasis. In the case of psoriasis, reduced plasma levels of C-reactive protein (CRP) and TNF- $\alpha$ were observed thus highlighting the ability of $B$. infantis to reduce systemic pro-inflammatory biomarkers and thus to act as a potential therapeutic approach in treating psoriatic disease [111] (Table 1 and Figure 2).

Sodium butyrate is produced by the gut microflora [145] and it is known for its effect on cell cycle [120], tumor growth factors (TGF- $\beta$ ) [121] and protease enzymes [122]. In various studies utilizing human keratinocyte (HaCaT) cells it was shown that exposure to sodium butyrate induced apoptosis by $50 \%$ through up-regulation of death receptor Fas with concomitant activation of caspases 8 and 3. In addition, increased expression levels of p52 and TGF- $\beta$ were also shown suggesting the involvement of cell proliferation and terminal differentiation as well [121]. Finally, a combined treatment protocol with sodium butyrate and PD153035 (an epidermal growth factor receptor inhibitor) was shown capable of enhancing keratinocyte differentiation [123]. Collectively, data suggest that sodium butyrate can act as a potential additional approach to the management of hyperproliferative skin diseases (including psoriasis) by modulating key cellular processes like apoptosis, proliferation 
and differentiation (Table 2 and Figure 2). To this end, a recent study examining the gut microbial composition in psoriatic patients revealed that a reduction of butyrate microbiota producers may have an impact on the established anti-inflammatory role of this short chain fatty acid [146] and thus explain, at least partially, its preventive role in psoriasis (among other disorders) [110]. In fact, F. prausnitzii (one of the most common microbial inhabitants of the large intestine) serves as an important source of butyrate which, in turn, (i) provides energy for colonocytes, (ii) reduces oxidative stress and (iii) exerts anti-inflammatory action (by triggering regulatory $\mathrm{T}$ cells) thereby conferring immune tolerance that goes beyond the GI tract $[38,100]$. Finally, another study has shown that psoriatic patients possess a substantially reduced number of F. prausnitzii when compared to healthy controls [101].

\subsection{Photoaging}

Skin aging is considered in the context of being either extrinsic or intrinsic. Extrinsic skin aging is caused by a number of environmental factors like UVR exposure (photo aging), smoking and life style habits (diet). In particular, photo aging is characterized by a specific phenotype that includes excessive loss of skin moisture, formation of deep and thick wrinkles, age spots, discoloration, loss of collagen and overall breakdown of the elastin network of the dermis, resulting in loss of skin elasticity [109]. To date, there are few studies investigating into the effects of probiotics/prebiotics to photo aging (Figure 1). In one such study, when hairless mice were administrated probiotic-containing fermented milk together with para-probiotic B. breve strain Yakult, and then subjected to UVB irradiation, it was shown an improvement in elasticity and appearance of the skin [124] together with suppression of elastase and IL-1 $\beta$ activity levels [125] (Table 1). These findings are in agreement with another study where administration of L. plantarum HY7714 to hairless mice and human epidermal fibroblasts was followed by UVB exposure and inhibition of MMPs-1,-2,-9 and -13 was recorded indicating rescued procollagen expression accompanied by inhibition of Jun N-terminal kinase phosphorylation and c-Jun expression levels. In addition, wrinkles formation and epidermal thickness were also reduced [147] (Table 1 and Figure 2). Moreover, L. plantarum HY7714 was shown to increase the mRNA levels of palmitoyl transferase (SPT) while reducing those of ceramide in human epidermal fibroblasts [148] (Table 1 and Figure 2). Furthermore, Galacto-oligosaccharides (GOS; one of the main prebiotics found in fermented food) were evaluated either alone or in the presence of probiotics (e.g., B. longum) in order to assess their effects on skin disease and inflammation. It was shown that the combination of probiotics and prebiotics prevented TEWL and reduced skin erythema whilst increasing the mRNA expression of CD44, TIMP-1 and Col1 [149] (Table 2 and Figure 2). Finally, in other studies, oligo-saccharides were also shown to prevent skin aging by modulating the expression of elastase-type proteases (through elastin receptors) [150] and/or prevent damage to the skin immune system [151].

\section{Conclusions}

Scientific and commercial interest on probiotics and prebiotics as well as their effect on human health and disease has increased in the last decade. The aim of this minireview article was to evaluate the role of pro- and prebiotics on the normal function of healthy skin as well as their role in the prevention and therapy of skin disease. Whilst a number of studies have determined the mechanisms by which some of these individual microorganisms can affect specific processes involved in the pathophysiology of skin disease, others have focused on more complex natural products (e.g., kefir) known to contain a mixture of probiotics but nevertheless also capable of exerting a potent beneficial effect. Overall, our manuscript favours the idea of the utilization of probiotics as a means of prevention and/or treatment options in skin disease. Such an alternative approach can have a huge impact in the context of therapy as it will aim to reduce the use of antibiotics and thus also reduce the side effects associated with their chronic usage. However, in order to do so, the precise mechanism of their action remains to be fully elucidated, whilst further studies need to explore their benefit in managing the outcome(s) of skin disease(s) at the clinical setting. 
Author Contributions: Conceptualization, M.I.P.; Methodology, V.L., M.I.P.; Data Curation, V.L.; Writing-Original Draft Preparation, V.L.; Writing-Review \& Editing, V.L., M.I.P.; Supervision, M.I.P.; Project Administration, V.L., M.I.P.; Funding Acquisition, M.I.P.

Funding: This research received no external funding.

Acknowledgments: The authors acknowledge financial support from Northumbria University at Newcastle, UK and specifically the Multidisciplinary Research Theme (MDRT) in Bio-economy including start-up funds (M.I.P) as well as a PhD studentship (V.L).

Conflicts of Interest: The authors declare no conflict of interest.

\section{References}

1. McGovern, P.E.; Zhang, J.; Tang, J.; Zhang, Z.; Hall, G.R.; Moreau, R.A.; Nunez, A.; Butrym, E.D.; Richards, M.P.; Wang, C.-S.; et al. Fermented beverages of pre- and proto-historic China. Proc. Natl. Acad. Sci. USA 2004, 101, 17593-17598. [CrossRef] [PubMed]

2. Sicard, D.; Legras, J.L. Bread, beer and wine: Yeast domestication in the Saccharomyces sensu stricto complex. C. R. Biol. 2011, 334, 229-236. [CrossRef] [PubMed]

3. Ozen, M.; Dinleyici, E.C. The history of probiotics: The untold story. Benef. Microbes 2015, 6, 159-165. [CrossRef]

4. Isolauri, E. Probiotics in human disease. Am. J. Clin. Nutr. 2001, 73, 1142-1146. [CrossRef]

5. Vandenplas, Y.; Zakharova, I.; Dmitrieva, Y. Oligosaccharides in infant formula: More evidence to validate the role of prebiotics. Br. J. Nutr. 2015, 113, 1339-1344. [CrossRef]

6. Gordon, S. Ellie Metchnikoff: Father of natural immunity. Eur. J. Immunol. 2008, 38, 3257-3264. [CrossRef]

7. Collins, M.D.; Phillips, B.A.; Zanoni, P. Deozyribonucleic acid homology studies of lactobacillus casei, Lactobacillus paracasei sp. nov., subsp. paracasei and subsp. tolerans, and Lactobacillus rhamnosus sp. nov., comb. nov. Int. J. Syst. Bacteriol. 1989, 39, 105-118. [CrossRef]

8. Report of a Joint FAO/WHO Working Group on Drafting Guidelines for the Evaluation of Probiotics in Food; Guidelines for the Evaluation of Probiotics in Food: London, ON, Canada, 2002; pp. 1-11.

9. Gasbarrini, G.; Bonvicini, F.; Gramenzi, A. Probiotics History. J. Clin. Gastroenterol. 2016, 50, S116-S119. [CrossRef] [PubMed]

10. Ouwehand, A.C.; Salminen, S.; Isolauri, E. Probiotics: An overview of beneficial effect. Antonie Van Leeuwenhoek 2002, 82, 279-289. [CrossRef]

11. Britti, M.S.; Roselli, M.; Finamore, A.; Merendino, N.; Mengheri, E. Regulation of immune response at intestinal and peripheral sites by probiotics. Biologia (Bratislava) 2006, 61, 735-740. [CrossRef]

12. Chen, C.C.; Allan Walker, W. Probiotics and the mechanism of necrotizing enterocolitis. Semin. Pediatr. Surg. 2013, 22, 94-100. [CrossRef]

13. Bansal, S.; Mangal, M.; Sharma, S.K.; Gupta, R.K. Non-dairy Based Probiotics: A Healthy Treat for Intestine. Crit. Rev. Food Sci. Nutr. 2016, 56, 1856-1867. [CrossRef]

14. Wang, X.; Farnell, Y.Z.; Peebles, E.D.; Kiess, A.S.; Wamsley, K.G.; Zhai, W. Effects of prebiotics, probiotics, and their combination on growth performance, small intestine morphology, and resident Lactobacillus of male broilers. Poult. Sci. 2016, 95, 1332-1340. [CrossRef]

15. Sánchez, B.; Delgado, S.; Blanco-Míguez, A.; Lourenço, A.; Gueimonde, M.; Margolles, A. Probiotics, gut microbiota, and their influence on host health and disease. Mol. Nutr. Food Res. 2017, 61, 1-15. [CrossRef] [PubMed]

16. Friedrich, A.D.; Paz, M.L.; Leoni, J.; Maglio, D.H. Message in a bottle: Dialog between intestine and skin modulated by probiotics. Int. J. Mol. Sci. 2017, 18, 1067. [CrossRef]

17. Thomas, C.M.; Versalovic, J. Probiotics-host communication. Gut Microbes 2010, 1, 148-163. [CrossRef]

18. Mori, N.; Kano, M.; Masuoka, N.; Konno, T.; Suzuki, Y.; Miyazaki, K.; Ueki, Y. Effect of probiotic and prebiotic fermented milk on skin and intestinal conditions in healthy young female students. Biosci. Microbiota Food Health 2016, 35, 105-112. [CrossRef]

19. Yamada, T.; Nagata, S.; Kondo, S.; Bian, L.; Wang, C.; Asahara, T.; Ohta, T.; Nomoto, K.; Yamashiro, Y. [Effect of Continuous Fermented Milk Intake Containing Lactobacillus casei Strain Shirota on Fever in Mass Infectious Gastroenteritis Rest Home Outbreak]. Kansenshogaku Zasshi 2009, 83, 31-35. [CrossRef] 
20. White, J.S.; Hoper, M.; Parks, R.W.; Clements, W.D.; Diamond, T.; Bengmark, S. The probiotic bacterium Lactobacillus plantarum species 299 reduces intestinal permeability in experimental biliary obstruction. Lett. Appl. Microbiol. 2006, 42, 19-23. [CrossRef] [PubMed]

21. Anukam, K.C.; Hayes, K.; Summers, K.; Reid, G. Probiotic Lactobacillus rhamnosus GR-1 and Lactobacillus reuteri RC-14 may help downregulate TNF-alpha, IL-6, IL-8, IL-10 and IL-12 (p70) in the neurogenic bladder of spinal cord injured patient with urinary tract infections: A two-case study. Adv. Urol. 2009, 680363.

22. Bennett, R.G.; Gorbach, S.L.; Greenough, W.B.; Bartlett, J.G. Treatment of Relapsing Clostridium difficile Diarrhea with Lactobacillus GG. Nutr. Today Suppl. 1996, 31, 35-38. [CrossRef]

23. Amara, A.A.; Shibl, A. Role of Probiotics in health improvement, infection control and disease treatment and management. Saudi Pharm. J. 2015, 23, 107-114. [CrossRef] [PubMed]

24. Boudeau, J.; Glasser, A.L.; Julien, S.; Colombel, J.F.; Darfeuille-Michaud, A. Inhibitory effect of probiotic Escherichia coli strain Nissle 1917 on adhesion to and invasion of intestinal epithelial cells by adherent-invasive E.coli strains isolated from patients with Crohn's disease. Aliment. Pharm. Ther. 2003, 18, 45-56. [CrossRef]

25. Mego, M.; Májek, J.; Končeková, R.; Ebringer, L.; Čierniková, S.; Rauko, P.; Kovac, M.; Trupl, J.; Slezak, P.; Zajac, V. Intramucosal bacteria in colon cancer and their elimination by probiotic strain Enterococcus faecium M-74 with organic selenium. Folia Microbiol. 2005, 50, 443-447. [CrossRef] [PubMed]

26. Thirabunyanon, M.; Boonprasom, P.; Niamsup, P. Probiotic potential of lactic acid bacteria isolated from fermented dairy milks on antiproliferation of colon cancer cells. Biotechnol. Lett. 2009, 31, 571-576. [CrossRef]

27. Abdin, A.A.; Saeid, E.M. An experimental study on ulcerative colitis as a potential target for probiotic therapy by Lactobacillus acidophilus with or without "olsalazine". J. Crohn's Colitis 2008, 2, 296-303. [CrossRef] [PubMed]

28. Imaoka, A.; Shima, T.; Kato, K.; Mizuno, S.; Uehara, T.; Matsumoto, S.; Setoyama, H.; Hara, T.; Umesaki, Y. Anti-inflammatory activity of probiotic Bifidobacterium: Enhancement of IL-10 production in peripheral blood mononuclear cells from ulcerative colitis patients and inhibition of IL-8 secretion in HT-29 cells. World J. Gastroenterol. 2008, 14, 2511-2516. [CrossRef]

29. Fujiya, M.; Musch, M.W.; Nakagawa, Y.; Hu, S.; Alverdy, J.; Kohgo, Y.; Schneewind, O.; Jabri, B.; Chang, E.B. The Bacillus subtilis Quorum-Sensing Molecule CSF Contributes to Intestinal Homeostasis via OCTN2, a Host Cell Membrane Transporter. Cell Host Microbe 2007, 1, 299-308. [CrossRef]

30. Kojima, K.; Musch, M.W.; Ren, H.; Boone, D.L.; Hendrickson, B.A.; Ma, A.; Chang, E.B. Enteric flora and lymphocyte-derived cytokines determine expression of heat shock proteins in mouse colonic epithelial cells. Gastroenterology 2003, 124, 1395-1407. [CrossRef]

31. Tao, Y.; Drabik, K.A.; Waypa, T.S.; Musch, M.W.; Alverdy, J.C.; Schneewind, O.; Chang, E.B.; Petrof, E.O. Soluble factors from Lactobacillus GG activate MAPKs and induce cytoprotective heat shock proteins in intestinal epithelial cells. Am. J. Physiol. Cell Physiol. 2006, 290, C1018-C1030. [CrossRef]

32. Petrof, E.O.; Kojima, K.; Ropeleski, M.J.; Musch, M.W.; Tao, Y.; De Simone, C.; Cheng, E.B. Probiotics inhibit nuclear factor- $\mathrm{KB}$ and induce heat shock proteins in colonic epithelial cells through proteasome inhibition. Gastroenterology 2004, 127, 1474-1487. [CrossRef]

33. Neish, A.S.; Gewirtz, A.T.; Zeng, H.; Young, A.N.; Hobert, M.E.; Karmali, V.; Rao, A.S.; Madara, J.L. Prokaryotic Regulation of Epithelial Responses by Inhibition of IKB- $\alpha$ Ubiquitination. Science 2000, 289, 1560-1563. [CrossRef] [PubMed]

34. Ma, D.; Forsythe, P.; Bienenstock, J. Live Lactobacillus reuteri Is Essential for the Inhibitory Effect on Tumor Necrosis Factor Alpha-Induced Interleukin-8 Expression. Infect Immun 2004, 72, 5308-5314. [CrossRef]

35. Tien, M.T.; Girardin, S.E.; Regnault, B.; Le Bourhis, L.; Dillies, M.A.; Coppee, J.Y.; Bourdet-Sicard, R.; Sansonetti, P.J.; Pedron, T. Anti-Inflammatory Effect of Lactobacillus casei on Shigella- Infected Human Intestinal Epithelial Cells. J. Immunol. 2009, 176, 1228-1237. [CrossRef]

36. Frick, J.S.; Schenk, K.; Quitadamo, M.; Kahl, F.; Köberle, M.; Bohn, E.; Aepfelbacher, M.; Autenrieth, I.B. Lactobacillus fermentum attenuates the proinflammatory effect of Yersinia enterocolitica on human epithelial cells. Inflamm. Bowel. Dis. 2007, 13, 83-90. [CrossRef] [PubMed]

37. Bai, A.P.; Ouyang, Q.; Zhang, W.; Wang, C.H.; Li, S.F. Probiotics inhibit TNF-alpha-induced interleukin-8 secretion of HT29 cells. World J. Gastroenterol. 2004, 10, 455-457. [CrossRef] 
38. Sokol, H.; Pigneur, B.; Watterlot, L.; Lakhdari, O.; Bermúdez-Humará, L.G.; Gratadoux, J.J.; Blugeon, S.; Bridonneau, C.; Furet, J.P.; Corthier, G.; et al. Faecalibacterium prausnitzii is an anti-inflammatory commensal bacterium identified by gut microbiota analysis of Crohn disease patients. Proc. Natl. Acad. Sci. USA 2008, 105, 16731-16736. [CrossRef]

39. Haller, D.; Russo, M.P.; Balfour-Sartor, R.; Jobin, C. IKK $\beta$ and phosphatidylinositol 3-kinase/Akt participate in non-pathogenic gram-negative enteric bacteria-induced RelA phosphorylation and NF- $\mathrm{KB}$ activation in both primary and intestinal epithelial cell lines. J. Biol. Chem. 2002, 277, 38168-38178. [CrossRef]

40. Ruiz, P.A.; Hoffmann, M.; Szcesny, S.; Blaut, M.; Haller, D. Innate mechanisms for Bifidobacterium lactis to activate transient pro-inflammatory host responses in intestinal epithelial cells after the colonization of germ-free rats. Immunology 2005, 115, 441-450. [CrossRef] [PubMed]

41. Jijon, H.; Backer, J.; Diaz, H.; Yeung, H.; Thiel, D.; McKaigney, C.; De Simone, C.; Madsen, K. DNA from probiotic bacteria modulates murine and human epithelial and immune function. Gastroenterology 2004, 126, 1358-1373. [CrossRef]

42. Resta-Lenert, S.; Barrett, K.E. Probiotics and commensals reverse TNF- $\alpha$ - and IFN- $\gamma$-induced dysfunction in human intestinal epithelial cells. Gastroenterology 2006, 130, 731-746. [CrossRef] [PubMed]

43. Kelly, D.; Campbell, J.I.; King, T.P.; Grant, G.; Jansson, E.A.; Coutts, A.G.; Petterson, S.; Conway, S. Commensal anaerobic gut bacteria attenuate inflammation by regulating nuclear-cytoplasmic shutting of PPAR- $\gamma$ and ReIA. Nat. Immunol. 2004, 5, 104-112. [CrossRef] [PubMed]

44. Are, A.; Aronsson, L.; Wang, S.; Greicius, G.; Lee, Y.K.; Gustafsson, J.A.; Petterson, S.; Arulampalam, V. Enterococcus faecalis from newborn babies regulate endogenous PPAR activity and IL-10 levels in colonic epithelial cells. Proc. Natl. Acad. Sci. USA 2008, 105, 1943-1948. [CrossRef] [PubMed]

45. Ewaschuk, J.B.; Walker, J.W.; Diaz, H.; Madsen, K.L. Bioproduction of Conjugated Linoleic Acid by Probiotic Bacteria Occurs. J. Nutr. 2006, 136, 1483-1487. [CrossRef] [PubMed]

46. Fitzpatrick, L.R.; Small, J.; Hoerr, R.A.; Bostwick, E.F.; Maines, L.; Koltun, W.A. In vitro and in vivo effects of the probiotic Escherichia coli strain M-17: Immunomodulation and attenuation of murine colitis. Br. J. Nutr. 2008, 100, 530-541. [CrossRef]

47. Yan, F.; Polk, D.B. Probiotic bacterium prevents cytokine-induced apoptosis in intestinal epithelial cells. J. Biol. Chem. 2002, 277, 50959-50965. [CrossRef]

48. Yan, F.; Cao, H.; Cover, T.; Whitehead, R.; Washington, M.K.; Polk, D.B. Soluble Proteins Produced by Probiotic Bacteria Regulate Intestinal Epithelial Cell Survival and Growth. Gastroenterology 2007, 132, 562-575. [CrossRef]

49. Watanabe, T.; Nishio, H.; Tanigawa, T.; Yamagami, H.; Okazaki, H.; Watanabe, K.; Tominaga, K.; Fujiwara, Y.; Oshitani, N.; Asahara, T.; et al. Probiotic Lactobacillus casei strain Shirota prevents indomethacin-induced small intestinal injury: Involvement of lactic acid Probiotic Lactobacillus casei strain Shirota prevents indomethacin-induced small intestinal injury: Involvement of lactic acid. Am. J. Physiol Gastrointest Liver Physiol. 2009, 297, 506-513. [CrossRef]

50. Sougioultzis, S.; Simeonidis, S.; Bhaskar, K.R.; Chen, X.; Anton, P.M.; Keates, S.; Pothoulakis, C.; Kelly, C.P. Saccharomyces boulardii produces a soluble anti-inflammatory factor that inhibits NF-kB-mediated IL-8 gene expression. Biochem. Biophys Res. Commun. 2006, 343, 69-76. [CrossRef]

51. Ménard, S.; Candalh, C.; Bambou, J.C.; Terpend, K.; Cerf-Bensussan, N.; Heyman, M. Lactic acid bacteria secrete metabolites retaining anti-inflammatory properties after intestinal transport. Gut 2004, 53, 821-828. [CrossRef]

52. Kim, H.G.; Kim, N.R.; Gim, M.G.; Lee, J.M.; Lee, S.Y.; Ko, M.Y.; Kim, J.Y.; Han, S.H.; Chung, D.K. Lipoteichoic Acid Isolated from Lactobacillus plantarum Inhibits Lipopolysaccharide-Induced TNF-Production in THP-1 Cells and Endotoxin Shock in Mice. J. Immunol. 2008, 180, 2553-2561. [CrossRef] [PubMed]

53. Matsuguchi, T.; Takagi, A.; Matsuzaki, T.; Nagaoka, M.; Ishikawa, K.; Yokokura, T.; Yoskikai, Y. Lipoteichoic Acids from Lactobacillus Strains Elicit Strong Tumor Necrosis Factor Alpha-Inducing Activities in Macrophages through Toll-Like Receptor 2. Clin. Diagn Lab. Immunol. 2003, 10, 259-266. [CrossRef]

54. Kim, S.O.; Sheikh, H.I.; Ha, S.D.; Martins, A.; Reid, G. G-CSF-mediated inhibition of JNK is a key mechanism for Lactobacillus rhamnosus-induced suppression of TNF production in macrophages. Cell Microbiol. 2006, 8, 1958-1971. [CrossRef] [PubMed] 
55. Klebanoff, S.J.; Watts, D.H.; Mehlin, C.; Headley, C.M. Lactobacilli and vaginal host defense: Activation of the human immunodeficiency virus type 1 long terminal repeat, cytokine production, and NF-kappaB. J. Infect. Dis. 1999, 179, 653-660. [CrossRef] [PubMed]

56. Miettinen, M.; Lehtonen, A.; Ilkka, J.; Matikainen, S. Lactobacilli and Streptococci Activate NF-kB and STAT Signaling Pathways in Human Macrophages. J. Immunol. 2000, 164, 3733-3740. [CrossRef]

57. Chiu, Y.H.; Hsieh, Y.J.; Liao, K.W.; Peng, K.C. Preferential promotion of apoptosis of monocytes by Lactobacillus casei rhamnosus soluble factors. Clin. Nutr. 2010, 29, 131-140. [CrossRef]

58. Iyer, C.; Kosters, A.; Sethi, G.; Kunnumakkara, A.B.; Aggarwal, B.B.; Versalovic, J. Probiotic Lactobacillus reuteri promotes TNF-induced apoptosis in human myeloid leukemia-derived cells by modulation of NF- $\mathrm{KB}$ and MAPK signalling. Cell Microbiol. 2008, 10, 1442-1452. [CrossRef]

59. Horinaka, M.; Yoshida, T.; Kishi, A.; Akatani, K.; Yasuda, T.; Kouhara, J.; Wakada, M.; Sakai, T. Lactobacillus strains induce TRAIL production and facilitate natural killer activity against cancer cells. FEBS Lett. 2010, 584, 577-582. [CrossRef]

60. Zhang, Y.; Li, J.; Tang, L. Cancer-preventive isothiocyanates: Dichotomous modulators of oxidative stress. Free. Radic. Biol. Med. 2005, 38, 70-77. [CrossRef]

61. Lee, D.E.; Huh, C.S.; Ra, J.; Choi, I.D.; Jeong, J.W.; Kim, S.H.; Ryu, J.H.; Seo, Y.K.; Koh, J.S.; Lee, J.H.; et al. Clinical evidence of effects of Lactobacillus plantarum HY7714 on skin aging: A randomized, double blind, placebo-controlled study. J. Microbiol Biotechnol. 2015, 25, 2160-2168. [CrossRef]

62. Pite, H. Effect of probiotic mix (Bifidobacterium bifidum, Bifidobacterium Lactis, Lactobacillus acidophilus) in the primary prevention of eczema: A double-blind, randomized, placebo -controlled trial. Rev. Port. Imunoalergol. 2010, 18, 385-386.

63. Brouwer, M.L.; Wolt-Plompen, S.A.; Dubios, A.E.; van der Heide, S.; Jansen, D.F.; Hoijer, M.A.; Kauffman, H.F.; Duiverman, E.J. No effects of probiotics on atopic dermatitis in infancy: A randomized placebo-controlled trial. Clin. Exp. Allergy 2006, 36, 899-906. [CrossRef]

64. Weston, S.; Halbert, A.; Richmond, P.; Prescott, S.L. Effects of probiotics on atopic dermatitis: A randomised controlled trial. Arch. Dis. Child. 2005, 90, 892-897. [CrossRef]

65. Rosenfeldt, V.; Benfeldt, E.; Valerius, N.H.; Pærregaard, A.; Michaelsen, K.F. Effect of probiotics on gastrointestinal symptoms and small intestinal permeability in children with atopic dermatitis. J. Pediatr. 2004, 145, 612-616. [CrossRef]

66. Kalliomäki, M.; Salminen, S.; Poussa, T.; Isolauri, E. Probiotics during the first 7 years of life: A cumulative risk reduction of eczema in a randomized, placebo-controlled trial. J. Allergy Clin. Immunol. 2007, 119, 1019-1021. [CrossRef]

67. Cho, S.H.; Strickland, I.; Boguniewicz, M.; Leung, D.Y. Fibronectin and fibrinogen contribute to the enhanced binding of Staphylococcus aureus to atopic skin. J. Allergy Clin. Immunol. 2001, 108, 269-274. [CrossRef]

68. Taylor, A.L.; Dunstan, J.A.; Prescott, S.L. Probiotic supplementation for the first 6 months of life fails to reduce the risk of atopic dermatitis and increases the risk of allergen sensitization in high-risk children: A randomized controlled trial. J. Allergy Clin. Immunol. 2007, 119, 184-191. [CrossRef]

69. Lee, J.; Seto, D.; Bielory, L. Meta-analysis of clinical trials of probiotics for prevention and treatment of pediatric atopic dermatitis. J. Allergy Clin. Immunol. 2008, 121, 116-121. [CrossRef]

70. Odamaki, T.; Iwabuchi, N.; Xiao, J. Effects and Mechanisms of Probiotics on the Prevention and Treatment of Allergic Rhinitis. In Lactic Acid Bacteria and Bifidobacteria: Current Progress in Advanced Research, 1st ed.; Sonomoto, K., Yokota, A., Eds.; Caiser Academic Press: Norfolk, UK, 2011; pp. 239-251.

71. Nogueira, J.C.; Gonçalves, M.C. Probiotics in allergic rhinitis. Braz. J. Otorhinolaryngol. 2011, 77, $129-134$. [CrossRef]

72. Jebur, M.S. Therapeutic efficacy of Lactobacillus acidophilus against bacterial isolates from burn wounds. N. Am. J. Med. Sci. 2010, 2, 586-591. [CrossRef]

73. Bassetti, M.; Vena, A.; Croxatto, A.; Righi, E.; Guery, B. How to manage Pseudomonas aeruginosa infections. Drugs Context. 2018, 7, 212527. [CrossRef]

74. Defez, C.; Fabbro-Peray, P.; Bouziges, N.; Gouby, A.; Mahamat, A.; Daurès, J.P.; Sotto, A. Risk factors for multidrug-resistant Pseudomonas aeruginosa nosocomial infection. J. Hosp. Infect. 2004, 57, 209-216. [CrossRef]

75. Livermore, D.M. Multiple Mechanisms of Antimicrobial Resistance in Pseudomonas aeruginosa: Our Worst Nightmare? Clin. Infect. Dis. 2002, 34, 634-640. [CrossRef] 
76. Peral, M.C.; Rachid, M.M.; Gobbato, N.M.; Huaman-Martinez, M.A.; Valdez, J.C. Interleukin-8 production by polymorphonuclear leukocytes from patients with chronic infected leg ulcers treated with Lactobacillus plantarum. Clin. Microbiol. Infect. 2010, 16, 281-286. [CrossRef] [PubMed]

77. Sonal Sekhar, M.; Unnikrishnan, M.K.; Vijayanarayana, K.; Rodrigues, G.S.; Mukhopadhyay, C. Topical application/formulation of probiotics: Will it be a novel treatment approach for diabetic foot ulcer? Med. Hypotheses 2014, 82, 86-88. [CrossRef] [PubMed]

78. Peral, M.C.; Huaman Martinez, M.A.; Valdez, J.C. Bacteriotherapy with Lactobacillus plantarum in burns. Int. Wound J. 2009, 6, 73-81. [CrossRef]

79. Atalan, G.; Demirkan, I.; Yaman, H.; Cihan, M.; Onder, F.; Sozmen, M. Effect of topical kefir application on open wound healing on in vivo study. Kafkas Univ. Vet Fak. Dderg. 2003, 9, 43-47.

80. Frei, R.; Akdis, M.; O'Mahony, L. Prebiotics, probiotics, synbiotics, and the immune system: Experimental data and clinical evidence. Curr. Opin. Gastroenterol. 2015, 31, 153-158. [CrossRef] [PubMed]

81. Pandey, K.R.; Naik, S.R.; Vakil, B.V. Probiotics, prebiotics and synbiotics- a review. J. Food Sci. Technol. 2015, 52, 7577-7587. [CrossRef]

82. Scholz-Ahrens, K.E.; Adolphi, B.; Rochat, F.; Barclay, D.V.; de Vrese, M.; Açil, Y.; Schrezenmeir, J. Effects of probiotics, prebiotics, and synbiotics on mineral metabolism in ovariectomized rats-Impact of bacterial mass, intestinal absorptive area and reduction of bone turn-over. NFS J. 2016, 3, 41-50. [CrossRef]

83. Hutkins, R.W.; Krumbeck, J.A.; Bindels, L.B.; Cani, P.D.; Fahey, G.; Goh, Y.J.; Hamaker, B.; Martens, E.C.; Mills, D.A.; Rastal, R.A.; et al. Prebiotics: Why definitions matter. Curr. Opin. Biotechnol. 2016, 37, 1-7. [CrossRef] [PubMed]

84. Schley, P.D.; Field, C.J. The immune-enhancing effects of dietary fibres and prebiotics. Br. J. Nutr. 2002, 87, S221-S230. [CrossRef]

85. Yamada, K.; Tokunaga, Y.; Ikeda, A.; Ohkura, K.; Mamiya, S.; Kaku, S.; Sugano, M.; Tachibana, H. Dietary effect of guar gum and its partially hydrolyzed product on the lipid metabolism and immune function of Sprague-Dawley rats. Biosci. Biotechnol. Biochem. 1999, 2163-2167. [CrossRef]

86. Yun, C.H.; Estrada, A.; Van Kessel, A.; Gajadhar, A.; Redmond, M.; Laarveld, B. Immunomodulatory effects of oat beta-glucan administered intragastrically or parenterally on mice infected with Eimeria vermiformis. Microbiol. Immunol. 1998, 42, 457-465.

87. de Preter, V.; Geboes, K.; Verbrugghe, K.; de Vuyst, L.; Vanhoutte, T.; Huys, G.; Swings, J.; Pot, B.; Verbeke, K. The in vivo use of the stable isotope-labelled biomarkers lactose-[N]ureide and [H4]tyrosine to assess the effects of pro- and prebiotics on the intestinal flora of healthy human volunteers. Br. J. Nutr. 2004, 92, 439-446. [CrossRef]

88. Cogen, A.L.; Nizetà, V.; Gallo, R.L. Skin microbiota: A source of disease or defence? Br. J. Dermatol. 2008, 158, 442-455. [CrossRef] [PubMed]

89. Grice, E.A. The skin microbiome: Potential for novel diagnostic and therapeutic approaches to cutaneous disease. Semin. Cutan. Med. Surg. 2014, 33, 98-103. [CrossRef]

90. Kano, M.; Masuoka, N.; Kaga, C.; Sugimoto, S.; Iizuka, R.; Manabe, K.; Sone, T.; Oeda, K.; Nonaka, C.; Miyazaki, K.; et al. Consecutive Intake of Fermented Milk Containing Bifidobacterium breve Strain Yakult and Galacto-oligosaccharides Benefits Skin Condition in Healthy Adult Women. Biosci. Microb. Food Health 2013, 32, 33-39. [CrossRef] [PubMed]

91. Suk, J.-H.; Park, J.-A.; Kang, S.-M. Effects of Lactobacillus reuteri Intake to Facial Skin Condition of Women. J. Kor. Soc. Cosm. 2018, 24, 661-670.

92. Kimoto-Nira, H.; Aoki, R.; Sasaki, K.; Suzuki, C.; Mizumachi, K. Oral intake of heat-killed cells of lactococcus lactis strain h61 promotes skin health in women. J. Nutr. Sci. 2012, 1, e18. [CrossRef]

93. Lee, J.B.; Suk, J.H.; Kang, S.M. Effect of Lactobacillus rhamnosus KCTC 5033 on the Appearance of Facial Skin due to the Ingestion of Probiotics and Paraprobiotics. J. Investig. Cosmetol. 2018, 14, 287-296.

94. McPherson, T. Current understanding in pathogenesis of atopic dermatitis. Ind. J. Dermatol. 2016, 61, 649-655. [CrossRef] [PubMed]

95. Czarnecka-Operacz, M.; Sadowska-Przytocka, A. Probiotics for the prevention of atopic dermatitis and other allergic diseases: What are the real facts? Alergol. Pol. Pol. J. Allergol. 2017, 4, 89-92. [CrossRef]

96. Kalliomäki, M.; Kirjavainen, P.; Eerola, E.; Kero, P.; Salminen, S.; Isolauri, E. Distinct patterns of neonatal gut microflora in infants in whom atopy was and was not developing. J. Allergy Clin. Immunol. 2001, 107, 129-134. [CrossRef] 
97. Prince, T.; Mcbain, A.J.; O’Neill, C.A. Lactobacillus reuteri protects epidermal keratinocytes from Staphylococcus aureus-induced cell death by competitive exclusion. Appl. Environ. Microbiol. 2012, 78, 5119-5126. [CrossRef]

98. Jung, G.W.; Tse, J.E.; Guiha, I.; Rao, J. Prospective, Randomized, Open-Label Trial Comparing the Safety, Efficacy, and Tolerability of an Acne Treatment Regimen with and without a Probiotic Supplement and Minocycline in Subjects with Mild to Moderate Acne. J. Cutan. Med. Surg. 2013, 17, 114-122. [CrossRef]

99. Vijayashankar, M.; Raghunath, N. Pustular psoriasis responding to Probiotics-A new insight. Our Dermatol. Online 2012, 3, 326-328. [CrossRef]

100. Lopez-Siles, M.; Khan, T.M.; Duncan, S.H.; Harmsen, H.J.M.; Garcia-Gil, L.J.; Flint, H.J. Cultured representatives of two major phylogroups of human colonic Faecalibacterium prausnitzii can utilize pectin, uronic acids, and host-derived substrates for growth. Appl. Environ. Microbiol. 2012, 78, 420-428. [CrossRef]

101. Eppinga, H.; Weilard, C.J.S.; Thio, H.B.; van der Wounde, C.J.; Nijsten, T.E.C.; Peppelenbosch, M.P. Similar depletion of protective Faecalibacterium prausnitzii in psoriasis and inflammatory bowel disease, but not in hidradenitis suppurativa. J. Crohns Colitis 2016, 10, 1067-1075. [CrossRef]

102. Jones, M.; Ganopolsky, J.G.; Labbe, A.; Gilardino, M.; Wahl, C.; Martoni, C.; Prakash, S. Novel nitric oxide producing probiotic wound healing patch: Preparation and in vivo analysis in a New Zealand white rabbit model of ischaemic and infected wounds. Int. Wound J. 2012, 9, 330-343. [CrossRef] [PubMed]

103. Isenberg, J.S.; Ridnour, L.A.; Espey, M.G.; Wink, D.A.; Roberts, D.D. Nitric oxide in wound-healing. Microsurgery 2005, 25, 442-451. [CrossRef] [PubMed]

104. Shah, M.M.; Saio, M.; Yamashita, H.; Tanaka, H. Lactobacillus acidophilus Strain L-92 Induces CD4 CD25 Foxp3 Regulatory T Cells and Suppresses Allergic Contact Dermatitis. Biol. Pharm. Bull. 2012, 35, 612-616. [CrossRef] [PubMed]

105. Karska-Wysocki, B.; Bazo, M.; Smoragiewicz, W. Antibacterial activity of Lactobacillus acidophilus and Lactobacillus casei against methicillin-resistant Staphylococcus aureus (MRSA). Microbiol. Res. 2010, 165, 674-686. [CrossRef]

106. Chapat, L.; Chemin, K.; Dubois, B.; Bourdet-Sicard, R.; Kaiserlian, D. Lactobacillus casei reduces CD8+T cell-mediated skin inflammation. Eur. J. Immunol. 2004, 3, 2520-2528. [CrossRef] [PubMed]

107. Hacini-Rachinel, F.; Gheit, H.; Le Luduec, J.B.; Dif, F.; Nancey, S.; Kaiserlian, D. Oral probiotic control skin inflammation by acting on both effector and regulatory T cells. PLoS ONE 2009, 4, e4903. [CrossRef]

108. Watanabe, J.; Sasajima, N.; Aramaki, A.; Sonoyama, K. Consumption of fructo-oligosaccharide reduces 2,4-dinitrofluorobenzene-induced contact hypersensitivity in mice. Br. J. Nutr. 2008, 100, 339-346. [CrossRef]

109. Tobin, D.J. Introduction to skin aging. J. Tissue Viabil. 2017, 26, 37-46. [CrossRef] [PubMed]

110. Codoner, F.M.; Ramirez-Bosca, A.; Climent, E.; Carrion-Gutierrez, M.; Guerrero, M.; Perez-Orquin, J.M.; Horga de la Parte, J.; Genoves, S.; Ramon, D.; Navarro-Lopez, V.; et al. Gut microbial composition in patients with psoriasis. Sci. Rep. 2018, 8, 3812. [CrossRef]

111. Groeger, D.; O’Mahony, L.; Murphy, E.F.; Bourke, J.F.; Dinan, T.G.; Kiely, B.; Shanahan, F.; Quigley, E.M. Bifidobacterium infantis 35624 modulates host inflammatory processes beyond the gut. Gut Microbes 2013, 4, 325-339. [CrossRef]

112. Wang, Y.; Kuo, S.; Shu, M.; Yu, J.; Huang, S.; Dai, A.; Two, A.; Gallo, R.L.; Huang, C.M. Staphylococcus epidermidis in the human skin microbiome mediates fermentation to inhibit the growth of Propionibacterium acnes: Implications of probiotics in acne vulgaris. Appl. Microbiol. Biotechnol. 2014, 98, 411-424. [CrossRef]

113. Kang, B.S.; Seo, J.G.; Lee, G.S.; Kim, J.H.; Kim, S.Y.; Han, Y.W.; Kang, H.; Kim, H.O.; rhee, J.H.; Chung, M.J.; et al. Antimicrobial activity of enterocins from Enterococcus faecalis SL-5 against Propionibacterium acnes, the causative agent in acne vulgaris, and its therapeutic effect. J. Microbiol. 2009, 47, 101-109. [CrossRef] [PubMed]

114. Weise, C.; Zhu, Y.; Ernst, D.; Ku, A.A.; Worm, M. Oral administration of Escherichia coli Nissle 1917 prevents allergen-induced dermatitis in mice. Exp. Dermatol. 2011, 20, 805-809. [CrossRef] [PubMed]

115. Huseini, H.F.; Rahimzadeh, G.; Fazeli, M.R.; Mehrazma, M.; Salehi, M. Evaluation of wound healing activities of kefir products. Burns 2012, 38, 719-723. [CrossRef]

116. Rodrigues, K.L.; Gaudino Caputo, L.R.; Tavares Carvalho, J.C.; Evangelista, J.; Schneedorf, J.M. Antimicrobial and healing activity of kefir and kefiran extract. Int. J. Antimicrob Agents 2005, 25, 404-408. [CrossRef]

117. Woodfolk, J.A. T-cell responses to allergens. J. Allergy Clin. Immunol. 2007, 119, 280-294. [CrossRef] 
118. Al-Ghazzewi, F.H.; Tester, R.F. Effect of konjac glucomannan hydrolysates and probiotics on the growth of the skin bacterium Propionibacterium acnes in vitro. Int. J. Cosmet. Sci. 2010, 32, 139-142. [CrossRef] [PubMed]

119. Bateni, E.; Tester, R.; Al-Ghazzewi, F.; Bateni, S.; Alvani, K.; Piggott, J. The Use of Konjac Glucomannan Hydrolysates (GMH) to Improve the Health of the Skin and Reduce Acne Vulgaris. Am. J. Dermatol. Venereol. 2013, 2, 10-14.

120. Daehn, I.S.; Varelias, A.; Rayner, T.E. Sodium butyrate induced keratinocyte apoptosis. Apoptosis 2006, 11, 1379-1390. [CrossRef]

121. Staiano-Coico, L.; Khandke, L.; Krane, J.F.; Sharif, S.; Gottlieb, A.B.; Krueger, J.G.; Heim, L.; Rigas, B.; Higgins, P.J. TGF- $\alpha$ and TGF- $\beta$ expression during sodium-N-butyrate-induced differentiation of human keratinocytes: Evidence for subpopulation-specific up-regulation of TGF- $\beta$ mRNA in suprabasal cells. Exp. Cell Res. 1990, 191, 286-291. [CrossRef]

122. Elder, J.T.; Zhao, X. Evidence for local control of gene expression in the epidermal differentiation complex. Exp. Dermatol. 2002, 11, 406-412. [CrossRef]

123. Leon Carrion, S.; Sutter, C.H.; Sutter, T.R. Combined treatment with sodium butyrate and PD153035 enhances keratinocyte differentiation. Exp. Dermatol. 2014, 23, 211-214. [CrossRef]

124. Sugimoto, S.; Ishii, Y.; Izawa, N.; Masuoka, N.; Kano, M.; Sone, T.; Chiba, K.; Miyazaki, K.; Ishikawa, F. Photoprotective effects of Bifidobacterium breve supplementation against skin damage induced by ultraviolet irradiation in hairless mice. Photodermatol. Photoimmunol. Photomed. 2012, 28, 312-319. [CrossRef] [PubMed]

125. Satoh, T.; Murata, M.; Iwabuchi, N.; Odamaki, T.; Wakabayashi, H.; Yamauchi, K.; Abe, F.; Xiao, J.Z. Effect of Bifidobacterium breve B-3 on skin photoaging induced by chronic UV irradiation in mice. Benef. Microbes 2015, 6, 497-504. [CrossRef] [PubMed]

126. Flanagan, M. The physiology of wound healing. J. Wound Care 2000, 9, 299-300. [CrossRef] [PubMed]

127. Rieger, S.; Zhao, H.; Martin, P.; Abe, K.; Lisse, T.S. The role of nuclear hormone receptors in cutaneous wound repair. Cell Biochem. Funct. 2015, 33, 1-13. [CrossRef]

128. Canesso, M.C.; Vieira, A.T.; Castro, T.B.; Schirmer, B.G.; Cisalpino, D.; Martins, F.S.; Rachid, M.A.; Nicoli, J.R.; Teixeira, M.M.; Barcelos, L.S. Skin Wound Healing Is Accelerated and Scarless in the Absence of Commensal Microbiota. J. Immunol. 2014, 193, 5171-5180. [CrossRef]

129. Robson, M.C. Wound infection: A failure of wound healing caused by an imbalance of bacteria. Surg. Clin. N. Am. 1997, 77, 637-650. [CrossRef]

130. Oryan, A.; Jalili, M.; Kamali, A.; Nikahval, B. The concurrent use of probiotic microorganism and collagen hydrogel/scaffold enhances burn wound healing: An in vivo evaluation. Burns 2018, 44, 1775-1786. [CrossRef]

131. Sikorska, H.; Smoragiewicz, W. Role of probiotics in the prevention and treatment of meticillin-resistant Staphylococcus aureus infections. Int. J. Antimicrob. Agents 2013, 42, 475-481. [CrossRef]

132. Codex Alimentarius. Codex Standards for fermented milks. In Milk and Milk Products, 2nd ed.; The European Community and its Member States (ECMS): Queenstown, New Zealand, 2011; pp. 6-16.

133. Farnworth, E.R. Kefir a complex probiotic. Food Sci. Technol. Bull. Funct. Foods 2006, 2, 1-17. [CrossRef]

134. Satir, G.; Guzel-Seydim, Z.B. How kefir fermentation can affect product composition? Small Rumin. Res. 2016, 134, 1-7. [CrossRef]

135. Irigoyen, A.; Arana, I.; Castiella, M.; Torre, P.; Ibáñez, F.C. Microbiological, physicochemical, and sensory characteristics of kefir during storage. Food Chem. 2005, 90, 613-620. [CrossRef]

136. Chen, H.C.; Wang, S.Y.; Chen, M.J. Microbiological study of lactic acid bacteria in kefir grains by culture-dependent and culture-independent methods. Food Microbiol. 2008, 25, 492-501. [CrossRef]

137. Rahimzadeh, G.; Fazeli, M.R.; Mozafari, A.N.; Mesbahi, M. Evaluation of anti-microbial activity and wound healing of kefir. Int. J. Pharm. Sci. Res. 2015, 6, 286-293.

138. Serafini, F.; Turroni, F.; Ruas-Madiedo, P.; Lugli, G.A.; Milani, C.; Duranti, S.; Zamboni, N.; Bottachini, F.; van Sinderen, D.; Margolles, A.; et al. Kefir fermented milk and kefiran promote growth of Bifidobacterium bifidum PRL2010 and modulate its gene expression. Int. J. Food Microbiol. 2014, 178, 50-59. [CrossRef]

139. Tsiouris, C.G.; Kelesi, M.; Vasilopoulos, G.; Kalemikerakis, I.; Papageorgiou, E.G. The efficacy of probiotics as pharmacological treatment of cutaneous wounds: Meta-analysis of animal studies. Eur. J. Pharm. Sci. 2017, 104, 230-239. [CrossRef] [PubMed] 
140. Drust, B.; Cable, N.T.; Reilly, T. Investigation of the effects of the pre-cooling on the physiological responses to soccer-specific intermittent exercise. Eur. J. Appl. Physiol. Occup. Physiol. 2000, 81, 11-17. [CrossRef] [PubMed]

141. Tett, A.; Pasolli, E.; Farina, S.; Truong, D.T.; Asnicar, F.; Zolfo, M.; Beghini, F.; Armanini, F.; Jousson, O.; De Sanctis, V.; et al. Unexplored diversity and strain-level structure of the skin microbiome associated with psoriasis. NPJ Biofilms Microbiomes 2017, 3, 14. [CrossRef] [PubMed]

142. Chang, HW.; Yan, D.; Singh, R.; Liu, J.; Lu, X.; Ucmak, D.; Lee, K.; Afifi, L.; Fedrosh, D.; Leech, J.; Vasquez, K.S.; et al. Alteration of the cutaneous microbiome in psoriasis and potential role in Th17 polarization. Microbiome 2018, 6, 154. [CrossRef]

143. Eppinga, H.; Thio, H.B.; Schreurs, M.W.J.; Blakaj, B.; Tahitu, R.I.; Konstantinov, S.R.; Peppelenbosch, M.P.; Fuhler, G.M. Depletion of Saccharomyces cerevisiae in psoriasis patients restored by Dimethylfumarate therapy (DMF). PLoS ONE 2017, 12, e0176955. [CrossRef]

144. Thio, H.H. The microbiome in psoriasis and psoriatic arthritis: The skin perspective. J. Rheumatol. Suppl. 2018, 94, 30-31. [PubMed]

145. Manning, T.S.; Gibson, G.R. Microbial-gut interactions in health and disease. Prebiotics. Best Pract. Res. Clin. Gastroenterol. 2004, 18, 287-298. [CrossRef]

146. Vinolo, M.A.R.; Rodrigues, H.G.; Nachbar, R.T.; Curi, R. Regulation of inflammation by short chain fatty acids. Nutrients 2011, 3, 858-876. [CrossRef]

147. Kim, H.M.; Lee, D.E.; Park, S.D.; Kim, Y.-T.; Kim, Y.J.; Jeong, J.W.; Jeng, S.S.; Ahn, Y.T.; Sim, J.H.; Huh, C.S.; et al. Oral administration of lactobacillus plantarum HY7714 protects hairless mouse against ultraviolet B-induced photoaging. J. Microbiol. Biotechnol. 2014, 24, 1583-1591. [CrossRef] [PubMed]

148. Ra, J.; Lee, D.E.; Kim, S.H.; Jeong, J.W.; Ku, H.K.; Kim, T.Y.; Choi, I.D.; Jeung, W.; Sim, J.H.; Ahn, Y.T. Effect of oral administration of Lactobacillus plantarum HY7714 on epidermal hydration in ultraviolet B-irradiated hairless mice. J Microbiol. Biotechnol. 2014, 24, 1736-1743. [CrossRef]

149. Hong, K.B.; Jeong, M.; Han, K.S.; Hwan Kim, J.; Park, Y.; Suh, H.J. Photoprotective effects of galacto-oligosaccharide and/or Bifidobacterium longum supplementation against skin damage induced by ultraviolet irradiation in hairless mice. Int. J. Food Sci. Nutr. 2015, 66, 923-930. [CrossRef] [PubMed]

150. Moczar, E.; Yvetter, S.G.; Robert, L.; Robert, A. Use of Oligosaccharides in the Prevention and Treatment of the Aging of Tissues. U.S. Patent No. 5910490, 16 August 1999.

151. Strickland, M.F.; Pelley, P.R.; Kripke, L.M. Cytoprotective Oligosaccharide from Aloe Preventing Damage to the Skin Immune System by UV Radiation. U.S. Patent No. 5824659, 20 October 1998. 